Cahiers d'études africaines

197|2010

Jeux de mémoire

\title{
Nervous Confessions
}

Military Memoirs and National Reconciliation in Mali

Confessions nerveuses : mémoires militaires et réconciliation nationale au Mali

\section{Alioune Sow}

\section{(2) OpenEdition}

\section{Journals}

Electronic version

URL: http://journals.openedition.org/etudesafricaines/15793

DOI: 10.4000/etudesafricaines. 15793

ISSN: $1777-5353$

\section{Publisher}

Éditions de l'EHESS

\section{Printed version}

Date of publication: 30 March 2010

Number of pages: 069-093

ISBN: 978-2-7132-2251-1

ISSN: 0008-0055

\section{Electronic reference}

Alioune Sow, "Nervous Confessions », Cahiers d'études africaines [Online], 197 | 2010, Online since 10 May 2012, connection on 20 April 2019. URL : http://journals.openedition.org/etudesafricaines/15793 ; DOI : 10.4000/etudesafricaines. 15793

This text was automatically generated on 20 April 2019.

(c) Cahiers d'Études africaines 


\title{
Nervous Confessions
}

\author{
Military Memoirs and National Reconciliation in Mali \\ Confessions nerveuses : mémoires militaires et réconciliation nationale au Mali
}

Alioune Sow

1 One notable outcome of Mali's dramatic 1991 transition to democracy after 23 years of military rule has been the multiplication of memory practices and discourses. The resulting "culture of memory" (Huyssen 2003: 14-15) points to a compulsion to engage with an unstable and vulnerable past, coveted, unknown and yet to be examined. This culture of memory, an understandable response to the anxieties of a transitional period, has been structured around a number of key axes and gestures, including memorialization, rehabilitation, revision, clarification and elucidation. Since 1991, almost all fields of Malian political, social and cultural life have engaged in profound interrogations of the past and the democratic transition, each with a different modality. In the political domain, for instance, events such as the 1991 National Conference, which took place five months after the March arrest of former president Moussa Traoré, was driven by a strong analytical ambition and brought together all the major political, legal and social actors of the nation (Clark 2000: 253) to scrutinize Traoré's regime, to engage with the dynamics of the political liberalization, and to anticipate the uncertainties of the transition to democracy (Robinson 1994). Events such as the televised trial of Moussa Traoré, presented by the new government as a pedagogical exercise for the nation and stimulated by the participation of key political figures, also contributed to the reexamination of Mali's political history.

2 Challenging the conventional, often distorted, historical narratives that dominated the Malian political and cultural sphere from 1968 to 1991, recent memory practices took a significant turn with the rehabilitation of Modibo Keita, leader of the independence and Mali's first president, deposed in Traoré's 1968 coup, particularly with the inauguration of the Memorial Modibo Keita (De Jorio 2003: 827-855) in 1999. In a similar vein, memorials and monuments have been carefully erected in the main Malian cities and in different quarters of the capital city of Bamako, not only to compete with the Westernand socialist- inspired memorial cultures that had dominated the Malian landscape for decades, but also, and most importantly, to celebrate the long and confused history of the 
Malian pro-democracy movement (Bayart 2000: 224) ${ }^{1}$. Through monuments and memorials, the beginning of the history of democratization could be articulated and the martyrs of political liberalization celebrated (Arnoldi 2007). This effervescence of memory has been culturally expansive. Music and dance festivals ${ }^{2}$ have revitalized segments of Malian culture kept dormant or prohibited during the Traoré regime. Exhibitions of the work of photographers such as Seydou Keita and Malick Sidibe have been instrumental in disclosing an alternative history of the independence period and igniting new critical discourse on the Malian postcolonial transition (Diawara 2002).

While most of the political, performance and visual aspects of the post-1991 Malian culture of memory described above have received a great deal of attention, the crucial contribution of literature to the process of memory has been largely ignored. Yet, in the past fifteen years, an unprecedented outpouring of life narratives and memoirs has offered additional ways to participate in the culture of memory. Written in celebratory, apologetic, confessional or accusatory tones, these narratives are authored by individuals as diverse as politicians, soldiers, journalists, lawyers, mine workers, and teachers. As regards the culture of memory, these narratives complement the more visible and celebratory public forms (memorials and sites) and institutionalized initiatives (the National Conference, various festivals) of remembering and examination. They are part of what Deborah Posel, following Charles Taylor, has called "the practices of negative commemoration" aimed primarily "at coming to terms with a violent and divisive past", "[setting] the record straight" and include versions of history by "voices previously marginalized" (Posel 2008: 122). They involve issues related to victimhood and include as motives and intentions regrets, remorse and sometimes accountability and apology. This paper is concerned with what I call narratives of negative commemoration, in relation to the more institutionalized aspects of the Malian culture of memory.

In the first part of the paper I will situate the recent self-centered discursive upsurge in the broader context of the transformations of Malian letters and briefly look at the critical relationship between Malian politics, literary practices and generic tendencies that prevailed during the Traoré's regime. After examining several motives of writing I will turn, in the second part, to two memoirs written by former officers of the regime, Assimi Souleymane Dembélé's Transferts définitifs (2003) and Soungalo Samaké's Ma vie de soldat (2007) in order to examine how these narratives engage with, and impact on, the culture of memory dominating Malian sociopolitical life since the early 1990 s.

\section{Negative Commemorations}

4 The democratic transition has brought radical transformations to the Malian "champ littéraire" (Bourdieu 1991: 24), revealing the extent of the degradation and disfigurement of the literary domain during the Traoré military regime. Some of the recent developments were longed for, such as the rehabilitation of literary figures Fily Dabo Sissoko (Ministère de la Culture du Mali 2001; Sidibé 2007) and Yambo Ouologuem. Others were unforeseen, like the rediscovery of the full range of Malian poetry, including a rich and varied regional militant poetry exemplified by the works of Albakaye Kounta and Adboulaye Ascofaré. Also unexpected was the mutation of fiction, a genre long engaged in condemning the excesses of the Malian state, which underwent a sudden crisis after democratization, before turning to more private orientations (Sow 2004). 
Prior to democratization, life narratives were almost nonexistent in independent Mali. Between 1968 and 1991, as in other parts of the continent, autobiographical practices were persistently dissuaded by the constant intervention of the Malian state in the form of monitoring, patronage, propaganda, censorship, surveillance, imprisonment and threats to authors' lives. Autobiographical practices were perceived as perilous, if not impossible, because of the implicit moratorium on the "I" imposed on the Malian champ littéraire. Additionally, a cursory examination of the scarce autobiographical production constituted by the works of Yoro Diakite (Une main amie, 1969), Aoua Keita (Femme d'Afrique, 1974), Seydou Traoré (Vingt-cinq ans d'escaliers ou la vie d'un planton, 1975) and Amadou Hampâté Bâ (Amkoullel, 1991), shows that most of the narratives published under the Traoré regime were strategically dedicated to childhood memories and experiences during the colonial years preceding Mali's independence. Most authors, such as Hampâté Bâ, who spent most of the military years outside the country, avoided addressing directly the dark period under Moussa Traoré. Seydou Traoré, Yoro Diakité and Aoua Keita all celebrated successful decolonization, active participation in the building of the nation, and promotion of a national culture without mention of the military regime.

6 The restrictions imposed on autobiographical writing after 1968 opened several avenues for fiction, whereby those engaged in the writing of the self and addressing issues of self representation partially circumvented the challenges to literary expression imposed by the regime (Savane 1986). Several genres emerged to substitute for suppressed autobiography. In the family novels of Diarra (Sahel sanglante sécheresse, 1981) and Konaté (Le Prix de l'âme, 1981; Une aube incertaine, 1985; Fils du chaos, 1986), the family and its crises become a site to express the problematic postcolonial Malian condition and to reproduce the patterns of domination and repression imposed by the regime. The dictator novels such as Keita's L'Archer Bassari (1984) and Diabaté's L'Assemblée des Djiins (1985) adroitly revealed the theatrical nature of the regime and its disentitlement of popular political power. Finally, Ibrahima Ly's prison novels (Toiles d'araignée, 1982; Les noctuelles vivent de larmes, 1988) depicted the drama of opposition and brutal repression, an experience very close to that of the political activist the author was.

7 The explosion of narratives of the self following the democratic transition can be read as a response to the policy of autobiographical containment that had lasted more than two decades. Unsurprisingly, renewed autobiographical activity materialized in the simultaneous publication of several narratives by victims of the regime. Most of them center on the traumatic encounter with the military regime and are structured around similar episodes of political activism, arbitrary arrest, interrogation and incarceration, articulating in dramatic fashion the experience of Malian political opponents of Traorés government. This experience is recalled for instance in Guediouma Samaké's Le chemin de l'honneur (1998), Samba Sangaré's Dix ans dans le bagne mouroir de Taoudenit (2001) and Amadou Traoré's Le salaire des libérateurs du Mali (2008). These texts denounce what Traoré (p. 7) calls "un pouvoir fasciste", they document the dreadful experiences of their authors in the Sahara desert prison camps and testify to the fate of other Malian activists who disappeared during the dictatorship. They expose the mechanisms of political repression, the catastrophic and agonizing experience of political prisoners, which was, until the publication of these works, difficult to imagine, figure and comprehend ${ }^{3}$. These texts invite a dialogue and a collective assessment of the past, the nature and peculiarities of the military regime and, of course, of the present and the adjustments and 
negotiations required during the democratic transition. For instance, as Samake and Traoré provide disturbing memoirs about their sojourns in the jails of Moussa Traoré, they also urge questioning the longevity of such a regime and blame what they refer to as a culture of bystanders, made of silence and obedience, apathy and passivity, which, at times, invaded all sectors of the society.

Mamadou Gologo, an influential member of the first independent Malian government, who spent several years in jail following the coup in 1968, offers a partial response to such interrogations. In his long and poignant autobiographical poem, "Dialogue avec les barreaux" (1999), Gologo reflects on commitment and the meaning of dissidence. Literally mourning his political ideals, he offers powerful examples of the tactics and processes of disorientation implemented by the state machine to annihilate political intent and desire through arbitrary arrest, torture and degrading conditions of detention. He also clarifies how, in this period of Malian history, the position, responsibility, participation and activities of the intellectual (Habermas 1989; Blanchot 1996) ${ }^{4}$ were compromised by the dismissive perception of the parasitic intellectual (Pensky 1999: 218) cultivated by the regime.

The questions about the past and the ambiguous attitudes towards the regime perhaps have been influenced by prior publications of remorseful narratives, highly apologetic and defensive, whose authors try to come to terms with their proximity to the state during dictatorship. Aporetic narratives written by former civil servants such as Mamadou Haidara's L'incompris (1995) and Sanoussi Konaté's Itinéraires (1997) suggest what Slavoj Zizek has called, referring to the fall of communist regimes, a "surplusobedience" syndrome, a condition noted among individuals not "engaged in dissident activities" but who "collaborate more than necessary, beyond the necessities of survival to enjoy excessive material and professional gains". Žižek (1997: 55) argues that a frequent reaction of such individuals following the defeat of the regime is "animosity" due to the humiliation prompted by the collapsed regime, which managed to "extract from them a surplus-obedience".

Bitterness and hostility are indeed main ingredients in L'incompris and Itinéraires but the narratives are also defensive, relying on confessions of personal crisis, emotional turmoil, blaming, misunderstanding and misidentification. The confessions are carefully distributed in the texts in an attempt to overcome the authors' relationships with the state. For instance, referring to their involvement in several cases of corruption and the derailment of national projects, both authors express remorse but simultaneously long for absolution by ascribing each action to the power of the corrupt bureaucratic administration or blaming what they refer to as their own "unconscious" participation or lack of judgment. Such examples are characteristic of a recurrent strategy of emphasizing the corrupting power of the military and the intoxicating effects of the political apparatus so as to wash off the guilt and, ultimately, restore personal integrity. Hence, the authors imply that decisions taken were less personal than subordinated to the ideology of the state and its forces in all sectors of Malian society. In addition, to further deflect condemnation, these writers appear to turn to a dubious rhetoric that attempts to present their involvement and troubling ideological positions as a failed subversive mode of participation, and to imply that their actions were somehow attempts to transform the apparatus from within.

11 While all these texts deserve further study, this brief review is sufficient to see how the political transition has led to the quasi simultaneous publication of both narratives 
written by the wounded victims of the military machine and exculpatory texts, dealing with accountability and complicity, written by individuals who benefited from the regime and were directly or remotely implicated in it. This concomitance reveals not only a common desire to engage with the past, but also nervousness about the modalities and outcome of such a process, raising ethical questions about the terms of the debate, its priorities and where the authority to talk about the past lies.

These issues are further raised in two narratives written by retired officers of the Malian army and former officials of the regime: Assimi Souleymane Dembélé's Transferts définitifs (2003) and Capitaine Soungalo Samaké's Ma vie de soldat (2007), which I am going to examine next. The publication of Transferts définitifs and Ma vie de soldat was unexpected and even surprising but was certainly facilitated by two crucial events. The first event was the trial of Moussa Traoré in 1992 for "crimes de sang" and "crimes économiques", during which a partial history of the practices of the regime and the army was revealed to the public. The second was the 1993 rehabilitation of the Malian army initiated by the interim government of Amadou Toumani Touré $e^{5}$ which followed a public apology to the Malian people (Villalon 2005: 56). These two events opened up and stimulated a debate about the vocation of the national army whose image was particularly tarnished by its role and responsibility in the previous regime, but they also created a favorable context for the publication of confessional narratives of those allied with the deposed regime.

It should be noted that these texts do not follow the dominant protocol and modes of confessions in situation of political transition to democracy as for the cases of Eastern Europe, Argentina, Brazil, Chile and South Africa. As John Borneman (1997) and Leigh Payne (2008) have demonstrated, the confessions of perpetrators in nations experiencing a democratic transition are often regulated by legislative and judiciary mechanisms and truth commissions, and their production is oriented towards obtaining amnesty. As opposed to this structure, the two Malian memoirs by former military officers are not attached to particular institutional mechanisms. Written by retired military leaders who participated in the coup in 1968 and then served the military regime, Transferts définitifs and Ma vie de soldat do not quite follow the conventions of the confessional mode. They are highly informative about the past regime yet their authors attempt to avoid justification of their own actions. They are written by perpetrators who take the opportunity, provided by the deliberative tendency of Malian society after democratization, to participate in the discourse on the reconstruction of the country yet they do not always acknowledge remorse, and their authors do not necessarily attempt "to depict themselves as victims" (Sampson 2003: 183).

Both Transferts and Ma vie de soldat were greeted as audacious narratives and commended as both estimable reportage on the Traoré's regime and documentation of Mali's darkest post- independence moments: the 1968 coup that ended Modibo Keita's socialist experiment, the mystery surrounding Keita's death in 1977, the conditions of the arrest and assassination of political and literary figures such as Ibrahima Ly and Fily Dabo Sissoko. Both narratives, however, were also greeted with circumspection: Why now? Why these narratives from major military figures in Mali? Perhaps the suspicious reception was anticipated, insofar as skilled paratextual activity by their respective editors supports, legitimizes and validates both texts. The preface to Transferts is by Moussa Konaté, a respected writer and prominent figure in the Malian literary scene, a successful independent editor in Bamako and, most important, famous for a brave pamphlet published at the end of the Traoré regime (Konaté 1990). Konaté presents 
Dembélé's book as decisive, authoritative and instructive: it is a book "terrible et édifiant: il montre du Mali une image que peu de gens soupçonnent [...] celui des brimades, des tortures, des assassinats dont personne ne parle" (p.5). Konaté insists that Dembélé's disclosures disrupt and demystify what could be called "la pensée malienne". For him, Transferts demonstrates that "the Malian thought" the country has been trying to preserve despite the Traoré regime, by drawing on secular traditions associated with notions such as resilience, solidarity and patriotism, in fact had been long eroded and replaced during the postcolonial period by "trente années de violence sans nom", "la chaîne des assassinats ininterrompue", "le goût du pouvoir", and "une vie faite de silences" (p. 5). According to Konaté, the text is not an apologia and allows a break with the culture of silence that dominated the thirty years of independent Mali. Konate ends his preface by praising Dembélé for "son honnêteté" and "son courage" (p.6) and identifying Dembélé's main motive as an attempt to bring understanding to the tormented history of postcolonial Mali.

Similar strategies and arguments are invoked to introduce Ma vie de soldat by Samaké's editor, Amadou Traoré, author of Le salaire des libérateurs du Mali mentioned above. The authority, scope and the significance of Samakés text are intensified, when readers discover that Traoré was himself a prisoner of the regime, arrested and tortured "sous les yeux" of Samaké: “J'ai subi des sévices physiques sous ses yeux, en même temps que mes camarades à Intadeinit en 1973 de la part des commandos parachutistes qu'il commandait, en représailles à une lettre que nous avions adressée à Moussa Traoré" (p. 7). While Traoré does not expand on his personal biography ${ }^{6}$, he makes sure to include a few crucial points aimed to influence reading, to mediate judgments of the author's behavior, and to justify a collaborative project which, Traoré suggests, might seem "incompréhensible, sinon même impossible entre deux personnes issues de régimes si différents" (pp.9-10). Special value is conferred on Samaké's work when Amadou Traoré asserts that after his own conviction and sentencing to "mourir sur le sable dans le Grand Nord" (p. 7) Samaké refused to carry out the order because of its arbitrary nature. He also indicates that Samake dutifully executed orders even if he disagreed because he was a soldier. Amadou Traoré insists on Samaké's importance as a witness because of his involvement in crucial episodes such as the military coup and the death of Modibo Keita (p.9). These assertions announce the content of the text but they also position it. Amadou Traoré insists on its pedagogical value of Ma vie de soldat for comprehending contemporary Malian history and, referring to his own experience, also emphasizes its conciliatory value. Identifying the text as a symbol of the new Mali, he insists on his "moral and political duty" as an editor to publish such a text for the sake of forgiveness, reconciliation and nationhood. He notes: "En réalité, pour nous, au-delà des hommes et des régimes, les affaires de la Nation méritent tous les sacrifices et tous les dévouements sans arrière pensée" (p. 10).

Both prefaces, emphasizing the "nobility" and the "virtue" of the books, underline the utility of the texts in the process of societal truth and reconciliation initiated since the fall of the Traoré regime. Moussa Konaté and Amadou Traoré insist on the necessity of such publications "par devoir de mémoire" and both promote them as valuable documents to discover and understand the military order of things and the mechanisms of power deployed by the ruling elite to keep the regime in place for more than two decades. Both prefaces comply with the legitimizing, instructive and deliberative role of the preface as defined by Mitterrand (1980), Genette (1987) and others, but in the 
particular case of the Malian military narratives they also assume two additional functions. The first one is to mediate the reception of the texts and foster conciliation in what is after all a renewed literary but also politically charged context by anticipating on possible reactions and divisions among readers regarding the unpredictable period of the military regime. The second one is to position the narratives as crucial and instrumental in the process of disclosure of the past, which implies for the readers the necessity of facing questions of abuses and human rights violations, and of working through responsibility, guiltiness and forgiveness, accountability and reconciliation. Basically, the prefaces strategically instruct about the requirements and necessary negotiations to initiate disclosure of the past and foresee reconciliation which depends on "coming to terms with the abuses and problems of the past, not attempting to forget or repress them" (Chapman 2008: 45).

Transferts and Ma vie de soldat reveal how a small group of officers, who gained power through the 1968 coup, initially supported by a population frustrated by Modibo Keita's "revolution active" (Dembélé 2003: 7) and hoping for the transformation of Malian politics (Samaké 1998: 95), engineered methods to exercise and maintain power, and to gradually erode human rights, freedom of speech and political movements of the Malian people. Both narratives bring to light the organizing principles of the regime and the gradual "criminalization of the state" (Bayart et. al. 1999) through corruption, routine and arbitrary arrest, falsification, interrogation, torture and assassination. In addition, these memoirs reveal the sheer incompetence of the members of the government and portray a "nouvelle race de cadres d'intellectuels et militaires et d'hommes d'affaires accaparant tout le système administratif, militaire, social, économique du pays [...]. Tout se résuma à ces deux objectifs: les honneurs et la fortune" (Dembélé 2003: 205). Dembélé and Samake divulge how the state progressively disempowered the population, capitalized on natural catastrophes (the drought of 1974), inequalities by manipulating the young, the poor and the illiterate, and perversely invaded private and public spheres to impose an authoritarian system similar to the one described by Todorov $(1996: 22,128)$ in his reflection on Nazi concentration camps and Soviets gulags where there was "no refuge, no escaping state's control". They reveal how this was implemented through domains as diverse as food distribution, national sports, music and entertainment ${ }^{7}$. They show how deception, dupery, and fabrication were essential tactics that notorious state representatives used to secure their authority and positions, and to arbitrarily and often violently undermine opponents and reformers by intervening in their family affairs, breaking up marriages and relationships (Dembélé 2003: 83).

Transferts and Ma vie de soldat attest principally to the crimes and tortures of the regime. They focus mainly on the centrality of two geographical sites in the policy of repression, Kidal and Taoudenit, where the penitentiaries notoriously known in Mali as "the concentration camps of the north" were located: "Vous savez, on ne peut pas qualifier Taoudenit. Tout ce que vous imaginez d'horrible, de malsain, de nauséabond, vous le trouvez à Taoudenit. C'est l'enfer on y vit quotidiennement avec la mort" (ibid.: 204). The martyrdom of political figures, intellectuals, students, and unknown citizens in these penitentiaries constitutes the core of these two narratives, which project experiences in the two camps as the paradigm of Malian oppression and symbols of the structure and system of the Traoré regime. Dembélé (p.64) movingly and chillingly recalls the degrading ceremonials to subjugate prisoners: 
"La seconde épreuve était celle du tapis d'honneur. Elle consistait à déshabiller les prisonniers et à les faire coucher sur le sable chaud, ventre à terre, côtes contre côtes. Les dos se présentaient alors comme un clavier de balafon: le lieutenant leur marchait dessus comme sur un tapis rouge d'honneur et invitait son successeur à faire de même"(p. 67).

19 He insists on the cruelty and insanity of camp guards who broke social bonds, the dehumanizing methods and processes of tortures, the rudimentary mechanics of death and murder, all fueled by filthy conditions and the exhaustion of inmates often forced to denounce each others, as well as the sadism of the supervisors of the camp such as the infamous Abdoulaye Niantao ${ }^{8}$, responsible for the deaths of dozens of prisoners:

"Le travail cessant à 19 heures, le lieutenant venait vérifier si la production journalière qu'il avait fixée était atteinte. Malheur si elle ne l'était pas! Alors d'une voix vibrant de colère, il criait aux soldats: 'Cognez! Cognez-moi ces traîtres! Qu'ils meurent parce que les morts ne racontent jamais les circonstances de leur mort. D'ailleurs, j'ai carte blanche puisque ce sont des condamnés à mort. Peu importe la manière. Cognez!'. Les coups pleuvaient, le sang giclait. Tout juste si le lieutenant ne demandait pas à boire le sang chaud, tant il exultait à vous voir saigner"(p. 64).

Samaké also describes the regime's horrendous methods by focusing on several experiences of victims in the Northern camps or in Bamako prisons. While Dembélé allows that he was not always present for tortures, Samake was directly involved in all the famous cases he reports. He was a member of the brigade that arrested Modibo Keita. He was in charge of the arrest of subversive students and intellectual figures such as Ibrahima Ly. He implemented surveillance methods and the deportation of most political prisoners to Kidal and Taoudenit. He was also responsible for the surveillance of major unionists, most notably Germaine Diarra, one of the few female union representatives who, after having been head- shaved and having spent days in the hands of the guards, had to prove to Samaké that she was "alive" by performing a morbid dance: "Il faut me montrer que tu es guérie: pour cela il faut sauter, dix fois, et chaque fois les talons doivent toucher aux fesses. Elle s'est exécuté" (Samaké p. 113). The multiple scenes of surveillance, arrest, humiliation and torture of dissidents as well as of military activities inside state factories and on campuses provide insights into the enduring prodemocratic and protest culture patiently cultivated by militants and systematically suppressed by the repressive apparatus of the regime until $1991^{\circ}$. In addition the authors disclose the regular imprisonment of Malian military figures, thus pointing to the schizophrenic nature of a military regime whose main agents had to be constantly monitored and frequently replaced to respond to the growing unrest of the Malian people over the government's corrupt practices (Samaké pp. 144-158, Dembélé pp. 164-206) ${ }^{10}$. The case of Yayoroba Diakité, who coordinated the 1968 coup with Moussa Traoré and then served as Mali's Prime minister from November 1968 to September 1969, illustrates perfectly such tendencies. Both texts dedicate significant pages to Diakités incarceration and agony and emphasize the cruel historical irony in his fate, as he created the penal colonies of Taoudenit and Kidal (Dembélé p. 52) but then, after being sentenced for treason against Traoré, died in the prison of his own making in 1969 (Dembélé p. 202). What the descriptions of Diakité's arrest and incarceration reveal is a regime functioning in a constant atmosphere of political intrigue and betrayal, weakness and opportunism very much in contrast with the image of the strong and rational regime the government had promoted since seizing power.

That both memoirists insist on Diakités tragic fate is also a way to tell us about the 
regime's strategies to counter moments of opposition within the party, and redefine its appearance in the eyes of the public opinion by sacrificing, in a rather theatrical mode, crucial political figures so as to obliterate them from the history of the country. Their insistence on Diakité's fate provides additional and strong evidences of the inhumane and often insane treatment of political prisoners and clarifies the culture of humiliation on which the totalitarian regime entirely relied. There is no better example of it than Dembélés rendering of Diakité's arrival in Taoudenit, when the head of the camp reads the official note of the creation of the camp signed by Diakité himself (p. 77) and then initiates a slow and long process of torture in which humiliation and profanity dominate:

"Le capitaine Yayoroba était devenu l'attraction de prédilection des geôliers. À tout moment on le faisait sortir pour le faire danser tout nu les danses réservées aux jeunes filles peules. L'assistance se gaussait à cause de son physique naturellement dodu. Quelle déchéance! se disait-il [...]. Triste sort que celui de cet officier intelligent! À chacune de ses incartades, correspondait un châtiment, le plus dur qu'il eût à supporter fut certainement celui du 'lit du premier ministre'. Ce châtiment consistait à le faire coucher sur un amas de barbelés faisant office de lit. On l'obligeait à s'y laisser tomber et à s'y rouler. Le malheureux se retrouvait tout transpercé et se vidait petit à petit de son sang".(Dembélé p. 79)

\section{Demons Obliquely Confronted}

Examples of arbitrary arrest, humiliation, violence, terror, pain and suffering in the multiple sites of Malian repression proliferate in the two narratives I am examining, but the "nobility" and "virtue" ascribed to both texts by their respective editors depend on more than the disclosure and enumeration of the regime's atrocities. The two qualities underlined by Moussa Konaté and Amadou Traoré in their respective prefaces also derive from the self-examination, judgment and attitudes of Dembélé and Samaké in the face of Malian history. Most particularly, both texts are haunted by the key events of 1968 and the figure of Modibo Keita, intimating that the arrest of the socialist president was certainly one of the most traumatic political events in the modern history of Mali and in their own political careers. However, Dembélé and Samakés approach to the events of 1968 and their remembrance of the first president of the independent Malian Republic are implemented in quite contrasting ways, which are worth examining for what they reveal about distinct modalities of disclosure of, and confrontation with, the past.

Around 1968 and the figure of Keita, Transferts définitifs expresses profound regrets for a series of military and government actions that determined the orientation of Mali for 23 years, and yet the narrative remains ambivalent as it contains no formulated repentance. The ambiguity of Transferts lies in the fact that Dembélé does not provide indications or explications about his exact role and commitment during the events of 1968. While recalling the functioning of the military regime and the implementation of its drastic repression policy, Dembélé constantly and strategically positions himself as a silent witness to the events and is often reluctant to fully engage with his participation and responsibility in events such as the arrest of Modibo Keita. Such configuration prompts questions about Dembélé's function and mandate during and after the events as well as about his responsibility in the tragic postcolonial history of the country. The deliberate attempt by Dembélé to avoid any direct association with the ideology and the actions of the regime highlights the difficulty of holding individual officers accountable for the tragic events and atrocities committed by the army and in the name of the army. 
However, in distancing himself from the outcomes of the coup and the arrest of Keita, Dembélé adopts an alternative form of penitence consisting in articulating the historical deceit and waste represented by the events of 1968, the tragic itinerary and the martyrdom of Modibo Keita.

Dembélé opens Transferts with the 1968 military coup itself, reveals details of its preparation, describes the confusion and disbelief following Modibo Keita's arrest, the state of emergency imposed by the regime, and the consolidation of the governing body of the military regime, the Comité militaire de libération nationale (CMLN). Very rapidly, however, Dembélé abandons the details of the event to focus instead on Keita's charismatic and seductive personality, stressing his influence across generations and recalling, in quasi-mystical terms, his appeal as the leader of Mali's independence. Keita is referred to in the text as the "guide", his physical presence often described with solemnity: "Le navire accosta et l'Homme apparut. Bon Dieu qu'il était beau, grand et majestueux" (p. 10). Recalling the arrest that ended Keita's regime, Dembélé combines facts and legends to cultivate the existing mystery ${ }^{11}$ surrounding this historical figure and the tragic days of the coup. For instance, he refers to rumors about the imminent fall of the regime and the arrest of the leader, supposedly revealed to Keita hours before the events by both a vindictive spiritual leader and a mental defective. The mythical aura around the fall of Keita is heightened by Dembélé's description of the silence that marked the first interrogation sessions of Keita by the CMLN officers. It is observed that some officers were "stunned", unable to fully measure the reality of the moment, and that most were silenced by Keita's captivating power and bewitching qualities: "En ce moment le Guide était devenu encore plus envoûtant, son regard était devenu plus pénétrant, sa voix plus limpide et sur le visage, une ébauche de sourire qui vous attire et vous décontenance à la fois" (p.15). In this depiction of Keita's charismatic personality, Dembélé offers anecdotes that signal confusion and emphasize the atmosphere of bewilderment during the moments of the arrest. He notes how some officials had gotten themselves drunk in order to be able to confront Keita, fearing his "pouvoir magique" (p. 16) and recalls that one official of the army went as far as using the honorific title "Simbo" (master, leader, chief) to address him (p. 16).

Yet in focusing on Keita's personality, authority and magnetism, Dembélé does not quite produce a panegyric. The two cleverly constructed chapters dedicated to Keita mainly describe his arrest and his imprisonment but do not neglect the pitfalls of his socialist regime. For instance, while recalling Keita's imprisonment, Dembélé does not focus on the conditions of detention alone but imagines instead how Keita might have interrogated his own legacy and expressed remorse over the tragedies that marked his presidency. According to Dembélé, Keita's own demons were Fily Dabo Sissoko and Hamadoun Dicko, whose arrest and deportation he had ordered after they led a 1962 protest against the government monetary policy ${ }^{12}$. Keita interpreted this first major demonstration against his policy as a threat to his regime, responding to the growing frustration of the population with extreme brutality. In centralizing this drama in the narration of Keita's imprisonment, Dembélé contends that the arrests and deaths of Sissoko and Dicko constituted the low point of Keita's presidency, Mali's "first tragedy" since independence (p. 25) and certainly an aberration in the celebrated nationalist history of the country. He thus resists blind rehabilitation of Keita, endorsing instead an objective reflexive mode of historical examination in which the deviations of Keita's regime are to be acknowledged, including the exactions of the famous militia (better 
known as the "police politique"), portrayed by Dembélé as "les aventuriers sans foi ni loi, le refuge des cadres véreux" (p. 43). Nonetheless, Dembélé uses the depiction of Keita's last days to partially rehabilitate the hero of independence by introducing several new elements to his biography. He reminds readers that following his arrest and deportation to Kidal, Keita lived almost the same fate as Sissoko and Dicko, an ordeal which, according to Dembélé, should be identified as expiatory. To credit this position, the author suggests that during his detention the "guide" often questioned and ultimately rejected his own authoritarian past. Dembélé illustrates this by highlighting Keita's subsequent contemplative personality, ascetic disposition (p.20), and his compassionate magnanimity towards his jailers (p. 45) all presented in the text as Keita's main acts of contrition.

By the end of the section on Modibo Keita, the accumulated virtues which Dembélé has used to describe Keita's character overcome the tragic version of history emanating from the pitfalls of the socialist regime. From this point on, Dembélé describes Modibo Keita as "l'ami, le conseiller et même l'éducateur avec qui chacun des hommes, soldats aussi bien que grades, s'empressaient avec plaisir d'avoir un brin de causerie" (p. 45). Keita's ultimate redemption comes when Dembélé laments the loss of a prophetic figure whose importance in the history of postcolonial Mali was unduly diminished by the military authorities who announced his death with a staggering radio statement presenting him as "un instituteur à la retraite". In contrast to this act of depreciation, Dembélé chooses sanctification, surrounding Keita's death with powerful Islamic references: "Cette même nuit une étoile, la plus éclatante, se détacha de son écrin azur et fonça vers l'Est (la direction de la Mecque), laissant derrière elle une longue trainée lumineuse" (p. 46). Skeptics would certainly see such an insistence on Modibo Keita as recuperative and a deliberate gesture to associate Transferts définitifs with the dominant political mood of the democratic period in which the book was published and in which Modibo Keita was in fact already rehabilitated. It can also be argued that the subtle tribute to Keita is perhaps the best demonstration Dembélé could find to express his aversion and disaffection for the ideology of the Traoré regime, to repent his proximity to the regime and, ultimately, to mitigate his own responsibility in the country's history.

Samake proposes another version of the 1968 events and a different reading of Modibo Keita's personality, contrasting with the mythical figure who dominates Dembélé's narrative. In Ma vie de soldat, the crisis of 1968 and the story of the coup in which Samaké took an active role are remarkably brief, largely anecdotal, and consistently legitimized. Samaké is never euphoric in his recalling the coup and makes sure to include in his narrative important indications of what the Traoré regime was really about, by focusing on lack of unity in the army, dissension and opportunism within the Comité militaire, and the preventive use of arrests and imprisonments to avert another coup. In contrast to Dembélé, Samaké remains deeply convinced of the necessity of the military intervention arguing that the coup was indispensable given the population and the army's many reasons for discontents. He does not hesitate to list them: bleak living conditions in the camps; a bitter rivalry between the army and the Keita government's feared "police politique"; abuses by the political militia in many quarters of the capital; the officers' anxiety about the gloomy prospect of military retirement to Keita's "champs collectifs"; one of the main realizations of the socialist ideology promoted from 1960 to 1968; and the exasperation of the peasants who had to dedicate time to the "collective field". After having registered the contradictions and abuses of the Keita's regime, Samaké shifts to a long depiction of Keita's interrogation sessions regarding the trial and the deaths of Fily 
Dabo Sissoko and Hamadoun Dicko, insinuating unconvincingly that the death of the two public figures was one of the main motivations for the coup.

As opposed to the majestic leader described in Dembéle's narrative, the Modibo Keita recalled by Samaké is, from the beginning, a defeated, exhausted and humiliated leader (pp. 78-79). This depiction helps the author to prepare his defense, close the gap between him and Keita, and ultimately allows him to negotiate a favorable position in relation to the dramas of 1968 and after. In recording Modibo Keita's arrest, his several years in detention and tragic end, Samaké, rather than discussing extensively on the ideological contradictions and political imperfections of the socialist regime, devotes instead most of the chapters to the close relationship he seems to have developed with the socialist leader, betting on the affective impact of such rapport. First, he credits himself with a number of charitable actions aimed at improving the former president's prison conditions and restoring his status and dignity. Second, Samake evokes his decisive role in Keita's relocation from the town of Kidal in the north down to the capital Bamako (p. 123). Finally, he maintains that Keita's life in the Bamako's "camp de parachutistes" improved dramatically because of his commitment to take personally charge of his meals, provide him with necessary furniture, and negotiate secretly family visits (pp. 124-130). As a result, familiarity and intimacy between the two men pervade the narrative and, by the time the chapters dedicated to the memory of Keita end, Samaké, almost triumphantly, recalls how a tearful and obliged Keita thanked him for his generosity: "Quand nous avons livré ces objets à Modibo, il m’a regardé et il a pleuré. Il m'a dit 'Soungalo tout ça c'est toi”' (p. 127). The description of Samaké's emotional ties to Modibo Keita concludes with several paragraphs on the last hours of the socialist leader and Samaké's frantic attempt to prevent his death. Such profusion of sentiments to characterize the relationship between the two men is troubling and at times astonishing, yet it grants Samaké an active and positive role of confidant and witness in the tragic biography of Modibo Keita and, most importantly, aims to exonerate him of any responsibility for the mysterious and still unexplained death of the former president of which Samaké has often been accused.

What is notable in the chapters dedicated to Keita is Samaké's attempt to set the record straight when it comes to his own proximity to the murky politics of the Traoré regime, and whenever possible, assert his own integrity and patriotism. The story of Keita is strategically situated in the narrative as it precedes the most poignant section of the book, wherein the author recalls his own arrest and condemnation to ten years of imprisonment for treason. The tale of Samaké's incarceration augments the already voluminous catalogue of the regime's atrocities, and points to the violence in the camps between political prisoners and their former prosecutors. The incarceration represents a turning point in the narrative as it attempts to provide readers with sufficient material to justify Samaké's absolution. His rendering of the terrifying decade spent in the camps and of his miserable condition upon his return to Bamako are meant to convey to readers the extent of his own expiation: “J'ai souffert de jour comme de nuit. J'ai souffert dans ma chair, j'ai souffert dans ma tête, dans mon cœur. Jamais je n'avais imaginé que je m'en sortirais à plus forte raison réaliser ce travail de mémoire" (p. 183). By the end of the narrative, and with the help of several landmark anecdotes about his difficult reintegration into the Malian society, and about the compassion and intervention of Amadou Toumani Touré, current president of Mali, the turn of destinies is complete: Samaké asserts himself as a victim of the persecution and injustice of the Traoré regime. 


\section{Imperfect Transactions and Pragmatic Confessions} configured narrative format in which Samaké situates himself, from the opening to the end of the text, "au-dessus de la mêlée", as an exemplary soldier, a man of action and of duty whose military vocation has never been tainted by the crises and dramas of postcolonial Malian history, and whose intuition kept him away from the unpredictable logics of the military regime. Samake repeatedly charts the events in which he demonstrated these personal qualities by insisting on his virtues of compassion and generosity towards the regime's victims. Still, he cites his obedience and sense of duty several times to justify his recourse to humiliation and degradation techniques as a legitimate mode of action to punish and silence men, women and young opponents to the regime. Invigilating, arresting and, sometimes, torturing were integral parts of his military mandate; at no time does he question the appalling nature of some of his decisions.

A close reading of Samaké's discourse demonstrates that this ambition to redefine himself as a victim of the regime is complicated by several assertions, which betray an inability to either critically assess his own past or examine the implications and consequences of the military regime's actions. The 1991 fall of Traoré's government is never read as the upheaval against twenty-three years of repression, military terror, and a frustrating and painful experience of a population longing for democracy. Rather, it is read as the outcome of rivalries among the officers ("les militaires se sont détruits") ${ }^{13}$, which, according to Samaké (p. 184), had derailed the initial project of emancipating the Malian population from Keita's government. Samaké is thus never apologetic about the military regime, truly believing in the military order of things, often pointing to its efficacy by praising the spirit, rigor, discipline and authority of the army and, most importantly, its perceived key achievements. In Samaké's view, the nature of the Traoré's regime and its failure are mainly due to the incompetence of a handful of individuals who took advantage of their position in the government, rather than to the army itself. As most military memoirists (Hill 1994: 229), Samaké remains persistently apolitical, his main concern being the demonstration of his allegiance to the army. At the same time, when inconvenient facts or contradictions emerge, he does not hesitate to legitimize his own involvement in some of the darkest episodes of postcolonial Mali by emphasizing his subordination to the military authority.

In that sense, Ma vie de soldat at times ends up being a rather confused and often incoherent self-panegyric in which the author deploys carefully selected episodes of his career as a soldier and officer to underline his role as a leader, to disclose his military skills, his initiative, his physical and emotional strength, not to mention his masculinity ${ }^{14}$ - The problem is that most of these episodes map onto the tragedies of the regime in which he was deeply involved. Hence, on the one hand, Samaké attempts to distance himself from some events by invoking the military mission and obedience of a soldier but, on the other hand, driven by his masculinist fixation, he contradicts himself by boasting that most of his actions were deliberate and carefully thought: "Ce qui pouvait m'amener à faire quelque chose. C'est ma conscience" (p. 180) ${ }^{15}$. Ultimately, Samaké struggles and often fails to be persuasive about the image of the honorable soldier he wants to impose. We are left with the confused portrait of an ambiguous character who, while, having 
witnessed and participated in some of the most tragic episodes of Malian history, now refuses to question the implications of his own actions and remains unable to condemn the cruelties of the regime he was serving. All these elements point to Samaké's hesitancies and contradictions in his attempt to confront Malian history and to his inability to reconcile with it. Reading Ma vie de soldat, one easily notices the author's inappropriate sarcasm as regards to the orientations of the military regime and his disdain for its victims, which the several chapters on Modibo Keita and the unverifiable precisions about the circumstances of his death do not compensate for. In his memoirs, Samake has attempted to set the record straight about his career, tried to rehabilitate himself to escape the rather negative reputation that the Malian public has of him, but never admitted guilt or responsibility.

It is difficult to sympathize with Samaké even if, ultimately, Ma vie de soldat is also about the tragic itinerary of a man who having risen to fame and enjoyed privileges for several years witnesses his world falling apart after an unexpected incarceration following perilous alliances. His tragic itinerary has still something very disturbing to say about the military regime and its agents who mainly apprehended government as a battlefield, who had no defined political agenda, were incompetent and, most distressingly, had absolutely no understanding of their own actions.

In contrast to Ma vie de soldat, there is no such a confusion and contradiction in Transferts définitifs, which closes with a meticulously written epilogue devoted to the meaning and implications of the narrative. Having recalled the "apocalyptic" scenes of the rampages and killings of the 1991 revolution, during which he was almost killed and came to realize that the military uniform associated him with a repressive regime, Dembélé closes his memoirs by underlining the symbolic function of his text. Relying on the themes of resentment, atonement and pardon, the epilogue expands on the difficult but necessary process of confession in order to learn from the dramatic episodes of the past, avoid historical repetition, and, most importantly, to pledge reconciliation. Dembélé calls for the reader's judgment, asserts the value of the confessional act, and adroitly assumes the "risk" (p. 215) posed by such endeavor while warning against the "danger mortel pour une paix sociale que représente le brouillard entretenu et peut-être intentionnellement dissimulateur de la vérité" (p. 215). Echoing Konaté's preface to his memoir, Dembélé assures readers of the utilitarian and reconciliatory functions of his text by presenting it as an invaluable source of documentation in order to remember the "faits et acteurs de notre histoire récente" (p. 215). For the writer, the memoir is analogous to penitence and, through "la révélation de la vérité", paves the way for "forgiveness" (p. 215) promising reconciliation and resistance to "la rancœur, [de] la haine, [de] la vengeance et [de] la cruauté" (p. 215).

Dembélé's reflexive and measured mode contrasts radically with Samaké's abrupt, impulsive and often rudimentary style. It is through this contrast that the different intentions and motivations of the two authors can be clearly discerned and the engagement of their narratives with the culture of memory dominating Malian sociopolitical life since the early 1990s can be measured. On the one hand, Dembélé's narrative aspires to speak to the collective interests by contributing to a new reflection on the 23 years of the Traoré's regime. In Transferts, Dembélé has pleaded guilty of complicity in the tragic history of postcolonial Mali by showing how he and certain members of the army were implicitly involved in the Traoré's oppression and remained passive witnesses to the drama of the authoritarian government. On the other hand, Samaké's narrative, far from being penitential, remains primarily individualistic and self- 
absorbed. Ma vie de soldat is principally an opportunity for the author to legitimize a personal itinerary, and rehabilitate his name through recounting what he perceives to be a conspiracy against him. The crucial role Samake played in the inception of the Moussa Traoré's regime and the realities of the military dictatorship are recalled in an impassive tone, with no sign of apology, and with a cynical indifference for the dramatic consequences of the military methods which often leaves the reader bemused.

\section{New Beginnings} and processes of political changes as well as the concessions and fault lines inherent in achieving it. In the Malian public sphere, these narratives are reminders of the manipulation of the national discourse by the regime between 1968 and 1991, instrumental in uncovering some of the most troubling and barbarous episodes of Malian history, and tackle issues of complicity, responsibility and amnesty which have been surprisingly ignored during the transition and yet necessary for the coming-to-terms with the past. Both texts seem to be a reminder of the necessity of interrogating the post-Traoré consensual approach to the past and to highlight a deficit in the national discourse of reconciliation. To begin with the celebrated Conférence nationale, where none of these actors was asked to participate, where none of the issues related to the violence of the past and the perpetrators of this violence were addressed in any depth, all in the name of the conference's commitment to a consensual and successful democratic transition. collective celebration of Mali's historical transformations. For instance, in September 2009, a few months after the Malian people participated in the dramatic commemoration of March 261991 President Amadou Toumani Touré in a speech celebrating the fortyninth anniversary of Malian independence, made a plea for "le devoir de mémoire" recalling the long independence struggle insisting on the necessity to celebrate 49 years of "actions politiques et culturelles" that led to democracy. In his speech on memory and democratic action, however, the 23 years of military rule were not mentioned once. One wonders whether such a fallacy of historical memory is an acceptable price to pay for the sake of unitary democratic consolidation.

33 I will conclude this essay by mentioning that, as regards to Malian letters, the two narratives that I have examined point to the rapid changes that have occurred in the Malian literary landscape since the fall of the Traore regime. They establish the prominence of personal writing since the onset of democratization and give evidence of 
the renewal of autobiographical practices in the country and, to a certain extent, on the continent. Until recently and with the exception of Southern Africa, very little space existed for military confessions and perpetrators' narratives. Autobiographical production and life-writing in general were dominated by narratives of the victims of totalitarian regimes reminding us of the persistent contradictions of some postcolonial African societies and illustrating in tragic manner the bad habits of military regimes. In this respect, the military memoirs published in Mali inaugurate a new genre of lifewriting, revealing new literary dynamics, original autobiographical determinations and intentions even as they bring to light new local modes of mediation, circulation and reception. As noted above, these narratives have been mediated by skilled prefaces aiming at a production of meaning of the texts with reference to a local history. Their presentation has also been conducted with carefully considered protocols seeking to facilitate and mitigate the reception and circulation of the texts, which started with the reproduction of excerpts in daily newspaper, and was followed by official and formal commentaries during roundtables, workshops and debates on national TV and radio. Indeed, all these elements point to the specificity of the Malian "regime of writing" (Barber 2006: 2). By clearly illustrating the multiplication and variations of autobiographical productions in African letters, they remind us of the need for, and the relevance of, the examination of local autobiographical practices and dynamics to further the "study of African textuality" (Barber 2007: 30) and enlarge our understanding of various African modes of writing the self (Mbembe 2002).

\section{BIBLIOGRAPHY}

ARNOLDI, M. J., 2007, "Mali: Monuments and Modernity in the urban imagination", Africa Today 54 (2): 3-24.

BARBER, K. (ed.), 2006, Africa's Hidden Histories: Everyday Literacy and Making the Self (Bloomington: Indiana University Press).

- 2007, The Anthropology of Texts, Persons and Publics: Oral and Written Culture in Africa and Beyond (Cambridge: Cambridge University Press).

BAYART, J.-F., 2000, “Africa in the World: a History of Extraversion”, African Affairs 99: 217-267.

BAYART, J.-F., ELLIS, S. \& HIBOU, B., 1999, The Criminalization of the State in Africa (London: Indiana University Press).

BLANCHOT, M., 1996, Les intellectuels en question (Paris: Fourbis).

BORNEMAN, J., 1997, Settling Accounts: Violence, Justice, and Accountability in Postsocialist Europe (New Haven: Princeton University Press).

BOURDIEU, P., 1991, Les règles de l'art. Genèse et structure du champ littéraire (Paris: Éditions du Seuil).

CHAPMAN, A. \& VAN DER MERWE, H. (eds.), 2008, Truth and Reconciliation in South Africa: did the TRC deliver? (Philadelphia: University of Pennsylvania Press). 
CLARK, A., 2000, "From Military Dictatorship to Democracy: the Democratization Process in Mali", in J. BINGEN, D. ROBINSON \& J. STAAZ (eds.), Democracy and Development in Mali (East Lansing: Michigan State University Press): 251-264.

coulibaly, P. B., 2008, “Tiekoro Bagayoko: un homme peu ordinaire”, Les Échos, 4 août.

DE JORIO, R., 2003, “Narratives of the Nation and Democracy in Mali: A View from Modibo Keita's Memorial", Cahiers d'Études africaines XLIII (4), 172: 827-855.

DEMBÉLÉ, A., 2003, Transferts définitifs (Bamako: Le Figuier).

DIAWARA, M., 2000, In Search of Africa (Cambridge: Harvard University Press).

- 2002, "The 1960s in Bamako", Politics and Culture 1. <http://aspen.conncoll.edu/ politicsandculture/adpage.html>.

GENETTE, G., 1987, Seuils (Paris: Éditions du Seuil).

Gologo, M., 1999, Mon cœur reste un volcan (Bamako: Éditions Donniya).

HABERMAS, J., 1989, The New Conservatism: Cultural Criticism and the Historians' Debate. Trans. and ed. Shierry Weber Nicholson (Cambridge MA: MIT Press).

HAIDARA, M., 1995, L'incompris (Bamako: Jamana).

HILL, L., 1994, “The Published Political Memoirs of Leading Nazis 1933-45”, in G. EGERTON (ed.), Political Memoir: Essays on the Politics of Memory (London: Routledge): 225-241.

HUYSSEN, A., 2003, Present Past: Urban Palimpsests and the Politics of Memory (Stanford: Standford University Press).

KONATÉ, S., 1990, Mali, ils ont assassiné l'espoir (Paris: L'harmattan).

- 1997, Itinéraires: souvenirs d'un cadre malien (Bamako: Jamana).

MBEMBE, A., 2002, “African Modes of Self-writing”, Public Culture 14 (1): 239-273.

MINISTÈRE DE LA CUlTURE DU MALI, 2001 Tradition et modernité dans l'œuvre littéraire de Fily Dabo Sissoko (Bamako: Jamana).

MitTERRAND, H., 1980, Le discours du roman (Paris: Presses Universitaires de France).

PAYNE, L., 2008, Unsettling Accounts (Durham NC: Duke University Press).

PENSKY, M., 1999, "Habermas and the Antinomies of the Intellectual", in P. DEWS (ed.), Habermas, a Critical Reader (Oxford: Blackwell): 211-237.

POSEL, D., 2008, "History as Confession: the Case of South Africa's Truth and Reconciliation Commission", Public Culture 20 (1) 54: 119-141.

ROBINSON, P., 1994, “The National Conference Phenomenon in Francophone Africa”, Comparative Studies in Society and History 36 (3): 575-610.

SAMAKÉ, G., 1998, Le Chemin de l'honneur (Bamako: Jamana).

SAMAKÉ, S., 2007, Ma vie de soldat (Bamako: La ruche à livres).

SAMPSON, S., 2003, “From Reconciliation to Coexistence”, Public Culture 15 (1): 181-186.

SANGARÉ, S., 2001, Dix ans au Bagne-mouroir de Taoudenit (Bamako: la Ruche à livres).

SAVANE, A., 1986, “Le roman des indépendances”, Notre Librairie 75-76: 123-127.

SIDIBÉ, M., 2007, Fily Dabo Sissoko, un grand sage africain (Bamako: Imprim Color). 
Sow, A., 2004, "The Curse of the Sons or the Betrayal of the Fathers? Rethinking the Family in Malian Literature", Journal of Mande Studies 4: 171-185.

TENAILLE, F., 2002, Music is the Weapon of the Future (Chicago: Review Press).

TODOROV, T., 1996, Facing the Extreme: Moral Life in the Concentration Camps (New York: Holt-

Metropolitan Books).

VILLALON, L. \& VON DOEPP, P., 2005, The Fate of Africa's Democratic Experiments: Elites and Institutions

(Bloomington: Indiana University Press).

ŽIžEK, S., 1997, The Plague of Fantasies (New York: Verso).

\section{NOTES}

1. Bayart reminds us that "contrary to a widely held opinion, the wave of pro- democracy of 1989-1991 agitation was caused less by the fall of the Berlin Wall or the speech of Francois Mitterrand at the Franco-African summit at La Baule in June 1990 or by pressure from aid donors than by the resurgence of old expectations and social movements of long standing, able to assert themselves once more as soon as international organizations had moderated their support for authoritarian regimes". "The monument dedicated to the student union leader Abdoul Karim Camara, known as Cabral, who was assassinated in March 1980, is one illustration of such a longstanding movement."

2. These include, for instance, Festival sur le Niger, Dense Bamako Danse, Écrans libres, and Rencontres de la photographie africaine, the dissemination of works of contemporary Malian artists whose productions provides radical, innovative forms for interrogating the past and examining contemporary and diasporic experience.

3. As the documentary Cendres et Soleil (1995) directed and produced by Stephane Drolet, shows a lot of wounded victims of the regime refuse to talk about their incarceration and prefer to remain silent. Popular figures such as Seydou Badian Kouyaté has also always refused to talk or write about his arrest and incarceration.

4. As a reminder, HABERMAS (1989: 73) defines the intellectual as someone who "intervene [s] on behalf of rights that have been violated, and truths that have been suppressed, reforms that are overdue, and progress that has been delayed". For Maurice BLANCHOT (1996: 55), the intervention of intellectuals is legitimised by a constant need to "répondre à des exigences morales à la fois obscures et impérieuses, puisqu'elles étaient de justice et de liberté".

5. Amadou Toumani Touré staged the coup that ended Traoré's regime, held office from March 1991 until June 1992 to lead the political transition, and was then elected after his retirement from the army in 2002. The rehabilitation of the army was ratified in January 1993 with the creation of "La journée de l'armée", January $20^{\text {th }}$.

6. This can be found in his Devoir de mémoire, devoir de vérité (Bamako: La Ruche à livres, 2005) and Le salaire des libérateurs du Mali (Bamako: La Ruche à livres, 2008).

7. For instance, the former Minister of Interior Tiekoro Bagayoko, overseeing Djoliba AC, a leading Bamako football team in the 1970s, transformed each match against the rival Stade Malien into a symbolic confrontation between two ideologies. Bagayoko also extended his reach into the musical scene when he supported and financed groups such 
as "Les Ambassadeurs du Motel", featuring Salif Keita and Kante Manfila. See TENAILLE (2002: 126) et DIAWARA (2000: 96-99).

8. The Malian television has recently aired a program in which Niantao was participating to the great dismay of the Malian public. The day following the program, several newspapers have reprinted interviews with survivors of the camps and excerpts from the narratives describing the sadism and the cruelty of Niantao (See for instance Le Républicain, 29/9/08) and raised questions about responsibility, complicity and accountability.

9. The students protests of 1979 (Samaké p. 115), the 1977 arrests of Ibrahima Ly and Bakary Koniba, and the assassination in 1980 of Cabral (Abdul Karim Camara), leader of the Union des Élèves et Étudiants maliens are examples of the events that trace the history of the democratic experience in Mali. All these events have inspired Souleymane Cissé's film, Finye (1982), dedicated to the confrontation between Malian youth and the regime.

10. In 1978, Moussa Traoré arrested three influential members of his regime, Tiécoro Bagayoko, Kissima Doukara and Karim Dembélé. Known as "La bande des trois", they were convicted of corruption and sent to the camps, where they died. This trial opened a new era for the regime marked by the renaming of the main authority, Comite militaire de Libération nationale. It became Union démocratique du peuple malien (UDPM).

11. The truth about the death of Modibo Keita is yet to be known. Since 1977, a series of rumors have circulated about his death, frequently presented as an assassination and incriminating his doctor or Soungalo Samaké.

12. More precisely, the 1962 demonstration in Bamako engaged the capital's merchants and traders to oppose the creation of the Franc malien (Dembélé pp. 22- 25). After a meeting organized by Keita, Sissoko, Dicko and Kassoum Touré, one of the richest traders in Mali, were accused of treason, counter-revolution and "complot contre la sécurité intérieure de l'État" (Dembélé p. 25). Tried by the Tribunal national populaire, they were initially condemned to death, then pardoned by Keita and sentenced to life imprisonment and hard labor. They died during their imprisonment. Amadou Traoré has published two books relating these events: Modibo Kéita: une référence, un symbole, un patrimoine national (Bamako: La Ruche à livres, 2005) and Devoir de mémoire, Devoir de vérité (Bamako: La Ruche à livres, 2005).

13. Samaké reminds us that in 1991 the Comité militaire was left with only two of the original 14 officers who conducted the 1968 coup.

14. His masculinist tendencies are apparent in descriptions of his "exploits" during the Algerian war (pp. 30-46), his recovery from a terrible helicopter accident (p. 57), his role in the coup (pp.69-89), his intuition about the opposition (p.96), and, in the private domain, his response to a problematic marital life.

15. In Mali, most of these aspects of Samaké's text have been perceived negatively. The reception in the press has been cautious and severe, celebrating the "travail de mémoire" and the invaluable documentation provided by Samaké but largely refusing absolution for a text "qui ne demande pas pardon aux victimes" (Le Républicain, 19/03/08). The text has been largely used in the press to question the circumstances of the death of Modibo Keita (Le Républicain, 11/08) and to reflect on certain personalities of the military regime. See for instance Pascal Baba coulibaly (2008). 


\section{ABSTRACTS}

Abstract

By focusing on two memoirs recently published by former officers of the 1968-1991 Malian military regime, Dembélé's Transferts définitifs and Soungalo Samaké's Ma vie de soldat, this essay examines a new autobiographical practice, which aims to uncover some of the most troubling episodes of Malian history, and raise questions about individual complicity, collective responsibility and amnesty. This essay demonstrates how these narratives engage with the culture of memory dominating current Malian sociopolitical life since the 1991 democratization, and complement the more visible and celebratory public forms and institutionalized initiatives of remembering and examination of the past. By inducing further and deeper reflections on the tremendous transformations brought by the mass demonstration of 1991, the determinations and processes of political changes, these narratives contribute in an unexpected manner to the discourse of national reconciliation in contemporary Mali.

Résumé

Focalisant principalement sur deux mémoires, Transferts définitifs de Dembélé (2003) et Ma vie de soldat de Soungalo Samaké (2007), écrits par des anciens officiers du régime militaire malien de 1968-1991, cet essai examine une nouvelle pratique autobiographique qui révèle certains des épisodes les plus troublants de l'histoire malienne tout en soulevant des questions cruciales relatives à la complicité individuelle, à la responsabilité collective et à l'éventualité d'une amnistie. Il s'agit de démontrer comment ces récits participent de la culture de la mémoire qui domine la vie sociopolitique malienne depuis la démocratisation de 1991, et complètent les formes visibles et publiques de commémoration ainsi que les initiatives institutionnalisées de l'examen du passé. En incitant des réflexions approfondies sur les transformations provoquées par les soulèvements populaires de mars 1991 et sur les déterminations et modalités du changement politique, ces récits contribuent d'une façon inattendue au discours et au processus de réconciliation nationale.

\section{INDEX}

Keywords: Mali, Democratic Transition, Memoirs, Memory Culture, Military Regime, National Reconciliation

Mots-clés: transition démocratique, Mali, mémoires, culture de la mémoire, régime militaire, réconciliation nationale 